\title{
EFFECT OF IMPLEMENTING TRAINING PROGRAM REGARDING CARE OF PATIENTS WITH UPPER GASTROINTESTINAL BLEEDING ON NURSES' KNOWLEDGE
}

\author{
Nesma Elsayed Ahmed Mandour 1, Prof Dr. El sayed Abed El maksood Khalil ${ }^{2}$, \\ Assist . Prof. Eman Saleh Shahin ${ }^{3}$, Assist. Prof .Shereen Ahmed Ahmed Qalawa 4 \\ Msc. Medical-Surgical Nursing, Faculty of Nursing-Ain Shams University ${ }^{1}$ \\ Professor of Internal Medicine, Faculty of Medicine -Mansoura University, Egypt ${ }^{2}$ \\ Assistant Professor of Medical-Surgical NursingFaculty of Nursing-Port-Said \\ University, Egypt ${ }^{3}$, Assistant Professor of Medical-Surgical NursingFaculty of Nursing- \\ Port-Said University, Egypt ${ }^{4}$
}

\begin{abstract}
Background: Upper gastrointestinal bleeding is a potentially life-threatening abdominal emergency that remains a common cause of hospitalization. The role of the nurse in managing a patient with upper GI bleeding requires specific attention. Aim: Evaluate effect of implementing training program regarding care of patients with upper GIT bleeding on nurses' knowledge. Subjects \& Method: Design: A Quasi experimental (pre/post -test) research design was used: Setting: study was conducted at Hematemesis Unit of Emergency Hospital located in Critical Situations and Convalescence Hospital affiliated to Mansoura University Hospitals. Subjects: Convenient samples of 25 male and female nurses who are dealing with upper gastrointestinal bleeding patients are selected from Hematemesis Unit of Emergency Hospital, Mansoura University, Egypt. Tools: Two tools were used to collect data; demographic characteristics of the nurses and nurses' knowledge assessment self-administrated questionnaire .A Quazi experimental (pre/post-test) design was used. Results: of the present study revealed that there was a highly statistically significant improvement in total knowledge of nurses regarding care of patients with upper gastrointestinal bleeding with $\mathrm{p}$-value of $(<0.001)$. Conclusion: the training program has a remarkable significant improvement on nurse's knowledge. Recommendations: a continuing training program be planned for and offered on regular basis to nurses in Hematemesis Unit to improve their knowledge regarding care of upper gastrointestinal bleeding patients and periodic monitoring of nurses knowledge by nursing audits and supervisors.
\end{abstract}

Keywords: Care, knowledge, Nurses, Training program, Upper gastrointestinal bleeding. 


\section{INTRODUCTION}

Upper gastrointestinal bleeding (UGIB) is potentially life-threatening abdominal emergency that remains a common cause of hospitalization and is defined as haemorrhage that involves the mouth to the duodenum proximal to the ligament of teritz (Cerulli \& Geibel, 2016;Tielleman, Bujanda \& Cryer, 2015).

Acute upper gastrointestinal bleeding (AUGIB) is one of the most common medical emergencies in the United Kingdom (UK), with an estimated incidence of 134 per 100,000, roughly equating to one presentation every $6 \mathrm{~min}$. Despite advances in therapeutics and endoscopy provision, mortality following AUGIB over the last two decades has remained high, with over 9,000 deaths annually in the UK (Siau, et al., 2017).

Upper gastrointestinal bleeding (UGIB) presents a clinical problem in Egypt with a significant mortality rate and according to the statistical records of the Hematemsis Unit at the emergency hospital, Mansoura University at 2017, a mortality rate was $14 \%$ of patients admitted to the Hematemsis Unit annually (Mansoura Annual Statistical Records, 2017) .

The role of the nurse in managing a patient with upper GI bleeding requires specific attention. In the first instance, the nurse assists a patient in hypovolemic shock; also patient comfort can be maintained by assessing the need for analgesia, the nurse should be confident in ABC (airway, breathing, circulation) resuscitation, and assess the patient's fluid and electrolyte status (Bayumi, 2016 ; Smith, 2012).

Upper gastrointestinal bleeding patients need special nursing care, to assure quality of this care, it is important to apply specific nursing training program that can entails knowledge and skills required by nurses in order to carry out care effectively, ameliorate patient care, improve cost effectiveness, decrease patient's problems and complications as well as improve patient's clinical outcomes (Bayumi, 2016).

\section{AIM OF STUDY:}

This study aimed to evaluate effect of implementing training program regarding care of patients with upper GIT bleeding on nurses' knowledge through:

- Assess nurses' knowledge regarding care of patients with upper GIT bleeding.

- Design training program for nurses regarding care of patients with upper GIT bleeding. 
- Implement a training program for nurses regarding care of patients with upper GIT bleeding.

- Evaluate effect of the training program regarding care of patients with upper GIT bleeding on nurses' knowledge.

\section{Hypothesis}

- Nurses' knowledge regarding care of patient with upper GIT bleeding will be improved after implementing the training program.

\section{SUBJECTS AND METHOD}

\section{Technical design:}

The technical design included; research design, study setting, subjects, and tools for data collection.

\section{Research design:}

A Quasi experimental (pre/post -test) research design was utilized to achieve the purpose of this study.

\section{Setting:}

This study was conducted at Hematemesis Unit of Emergency Hospital located in Critical Situations and Convalescence Hospital affiliated to Mansoura University Hospitals.

\section{Subjects:}

A Convenient sample consisted of all available nurses (25 nurses) providing care for patient with upper GIT bleeding at the above mentioned setting and accepted to participate in the study.

\section{Tools for Data Collection:}

The following two tools were utilized to collect data pertinent to the current study:

Tool 1: Demographic characteristics of the nurses: This part composed of closed ended questions including age, gender, job .etc.

\section{Tool 2: Nurses' knowledge assess ment self-administrated questionnaire:}

This tool was developed by the researcher based on reviewing relevant related literature (Lewis et al., 2016; Urden, Stacy \& Laugh, 2015; Dewit \& Kumagai, 2013) to collect data related to two main aspects. The first one was nurses' knowledge related upper GIT 
bleeding disease, and the second one was nurses' Knowledge about nursing care for upper GIT bleeding patients.

\section{Part 1: knowledge related upper GIT bleeding disease:}

This was composed of 8 closed ended questions including definition, causes, signs and symptoms, investigations, risk factors, complications, therapeutic regimen and medications.

\section{Part 2: Knowledge about nursing care for upper GIT bleeding patients:}

This was composed of 5 closed ended questions including items of nursing care, diet regimen, items of maintain hemodynamic stability, items of gastric lavage and discharge instruction .

\section{Scoring system for nurses' knowledge:}

Scoring system was graded according to the items of interviewing questionnaire sheet; the answer of respondent (nurses) was evaluated through using key answer prepared by the researcher. The total score of the knowledge was (71) grades, (100\%). Each correct answer was scored one (1) grade, and zero for wrong answer or didn't know. The total knowledge was classified as the following:

$>$ Satisfactory $\geq 75 \%$

$>$ Unsatisfactory $<75 \%$

\section{1) Operational design:}

The operational design consisted of preparatory phase, validity and reliability, pilot study, field work.

\section{Preparatory phase:}

This phase involved reviewing of the current and past, local and international recent related literature and different studies related to theoretical knowledge of the research and various aspects of this issue using books, articles, internet, journals and official sites as PubMed, eMedicine, Medscape, Medline plus and National Health Library in order to develop the data collection tools.

\section{Validity}

Testing validity was used for the modified tools and the designed booklet to determine whether the tools cover the aim. The stage developed by a Jury of seven experts from medical and nursing staff; two professor of internal medicine at Faculty of 
Medicine , Mansoura University and five lecturers of Medical-Surgical Nursing at Faculty of Nursing, , Port Said University.

\section{Reliability:}

Testing reliability of the proposed tools was done by Cronbach's alpha test, showed high

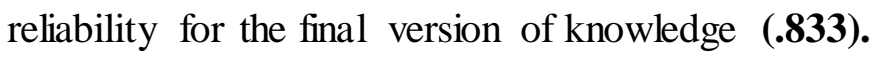

\section{Pilot study:}

The pilot study was applied on three nurses (10\%) of the study sample to test the applicability of tools, arrangement of items, and to estimate the time needed for each tool and for testing the feasibility of research process. Nurses included in the pilot study were excluded from the study group after modifying the tools.

\section{Field work:}

The collection of data, the implementation of the training program and the evaluation lasted over a period of 4 months starting from the beginning of April 2017 up to the end of July, 2017.

The study was conducted through four phases: assessment phase, program development phase, implementation phase and evaluation phase.

\section{Assessment phase}

1. The researcher started by introducing herself to the nurses, then giving them a brief idea about the aim of the study.

2. Verbal consent was obtained from each participating nurse prior to his /her inclusion into the study.

3. The researcher introduced the nurses' knowledge assessment self-administrated questionnaire to each nurse individually before applying the training program and asked them to complete it. The tool was filled in about 20 minutes to 30 minutes.

\section{Training Program development phase:}

- The training program was developed on the basis of the identified needs and demands of nurses gathered in phase I, in the light of the most recent literature review.

- The researcher designed a plane for the training program implementation. This plan designed to include two sessions were implemented in four weeks. Each week included three groups of nurses. One day for each group, each group contained five nurses from 
hematemesis unit. The time spent in explanation with each group was from 45 minute to one hour.

- The program teaching strategy was determined through choosing the appropriate teaching method which was in the form of lecture, small group discussion, and recommendation and appropriate teaching media which was in the form of handout, power points and auto visual material.

\section{III- The implementation phase:}

- At the beginning, the studied nurses were divided into five groups each group consisted of five nurses, then each group was gathered at a conference room separately. The training program was implemented for four weeks at a rate of one session per 2 weeks for five groups (three days per week). Each session took from 45 minutes to 1 hour per day.

- There was an explanation about the introduction and the importance of the training program, presentation of the program plan and presentation of the learned objectives of the program to each group separately.

- A copy of handout was given to each nurse to facilitate their remembering to the knowledge and to help for reviewing at any time.

\section{IV-Evaluation of the program:}

1. After applying the training program sessions the evaluation of the studied nurses was done immediately within one month to determine the effect of training program on nurse's knowledge using the study tools: nurses' knowledge assessment selfadministrated questionnaire (posttest).

2. Comparison between pre, and posttest findings was made to evaluate the effect of the training program on the nurse's knowledge toward upper GIT bleeding patients through program phases.

\section{2) Administrative design:}

\section{Ethical considerations:}

An official permission was obtained from the Dean of Faculty of Nursing, Port Said University and the director of emergency hospital at Mansoura University before conducting the study. Additional oral consent was obtained from the nurses and they were assured that the information would be used for research purpose only (confidential). 


\section{3) Statistical design:}

\section{Statistical analysis:}

All collected data were organized, categorized, tabulated, entered, and analyzed by using computer SPSS, (Statistical Package for Social Sciences), soft-ware program version 15, which was applied to frequency tables, statistical significance and associations were assessed using $\mathrm{X}^{2}$ : Chi-Square test and Wilcoxon singed ranks test $(\mathrm{Z})$ to detect the relation between the variables ( $\mathrm{P}$ - value). Mean and standard deviation were also used.

The observed differences and associations were considered as the following:

Non-significant (NS)

$$
\begin{gathered}
\mathrm{p}>0.05 \\
\mathrm{p} \leq 0.05
\end{gathered}
$$

Significant (S)

\section{RESULTS:}

Table (1): portrays that about $80 \%$ of the studied nurses were in age group of $20-40$ years with mean age of $28.36 \pm 7.58$ years old. Regarding job of the studied nurse, $88 \%$ of them were worked as a staff nurse. Concerning years of experience, it was found that $40 \%$ of the studied nurses had more than 6 years of experience. Relating to previous training program about nursing care for patient with upper GIT bleeding, it was found that $68 \%$ of the studied nurses did not have previous training program.

Figure (1): depicts that $68 \%$ of the studied nurses were females.

Figure (2): reveals that $60 \%$ of the studied nurses had technical institute level of education.

Figure (3): reveals that ,76.0\% of the studied nurses in pre phase of program had unsatisfactory total knowledge while in post implementation of the training program, it was found that $92.0 \%$ of them had satisfactory total knowledge with a highly statistical significant differences at all phases of implementing the training program with $\mathrm{p}$-value of $(<0.001)$.

Table (2): depicts that there were statistical significant correlation found between nurses' educational level, job and their total knowledge scores in pre implementation of training program with $\mathrm{p}$ - value of 0.005 and 0.001 respectively. 
Table (1): Demographic Characteristics of studied nurses $(n o=25)$.

\begin{tabular}{|c|c|c|}
\hline Socio-demographic characteristics & No & $\%$ \\
\hline \multicolumn{3}{|l|}{ Age group } \\
\hline$<20$ & 1 & 4.0 \\
\hline $20-40$ & 20 & $\mathbf{8 0 . 0}$ \\
\hline$>40$ & 4 & 16.0 \\
\hline Mean \pm SD & \multicolumn{2}{|c|}{$28.36 \pm 7.58$} \\
\hline \multicolumn{3}{|l|}{ Job } \\
\hline Staff nurse & 22 & $\mathbf{8 8 . 0}$ \\
\hline Head nurse(give direct care for patient) & 3 & 12.0 \\
\hline \multicolumn{3}{|l|}{ Years of experience } \\
\hline$<2$ years & 6 & 24.0 \\
\hline 2- 4 years & 3 & 12.0 \\
\hline $4<6$ & 6 & 24.0 \\
\hline$>6$ years & 10 & 40.0 \\
\hline \multicolumn{3}{|l|}{ Previous Training course } \\
\hline Yes & 8 & 32.0 \\
\hline No & 17 & 68.0 \\
\hline
\end{tabular}

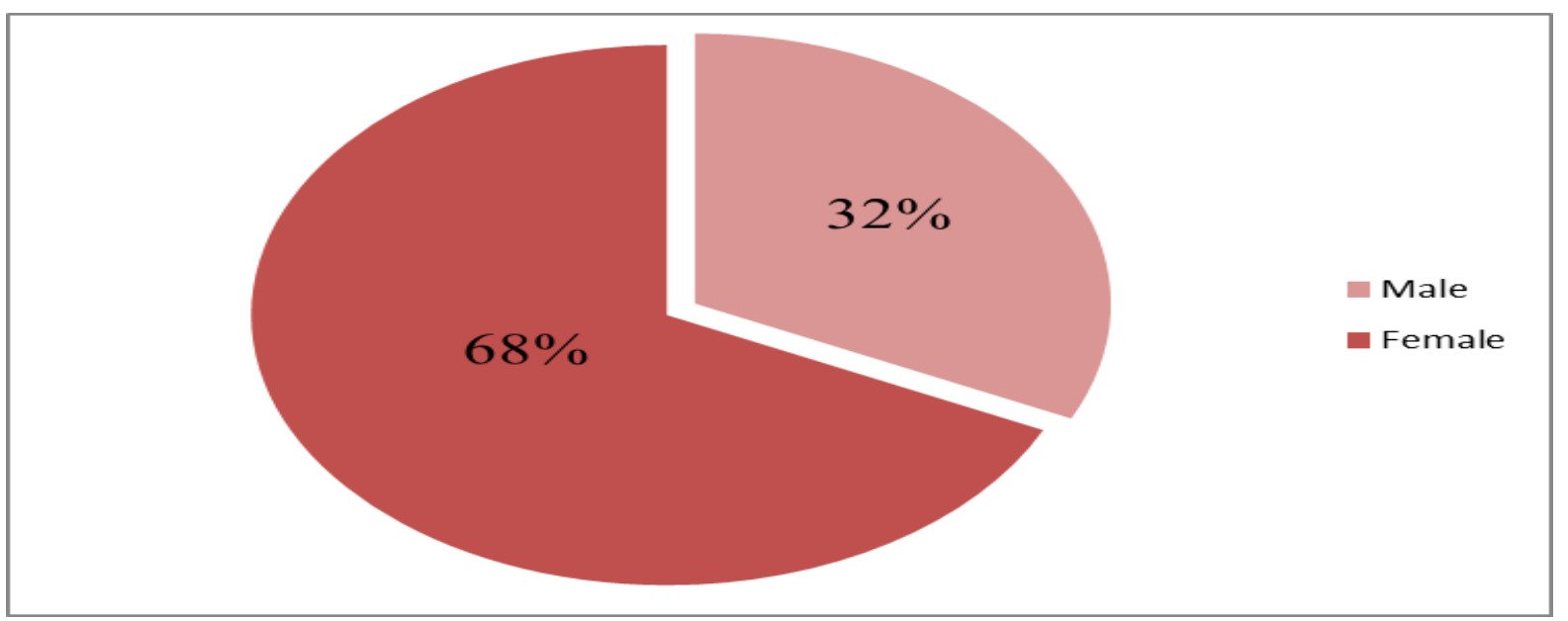

Figure (1): Distribution of the Studied Nurses According to their Gender $(n=25)$. 


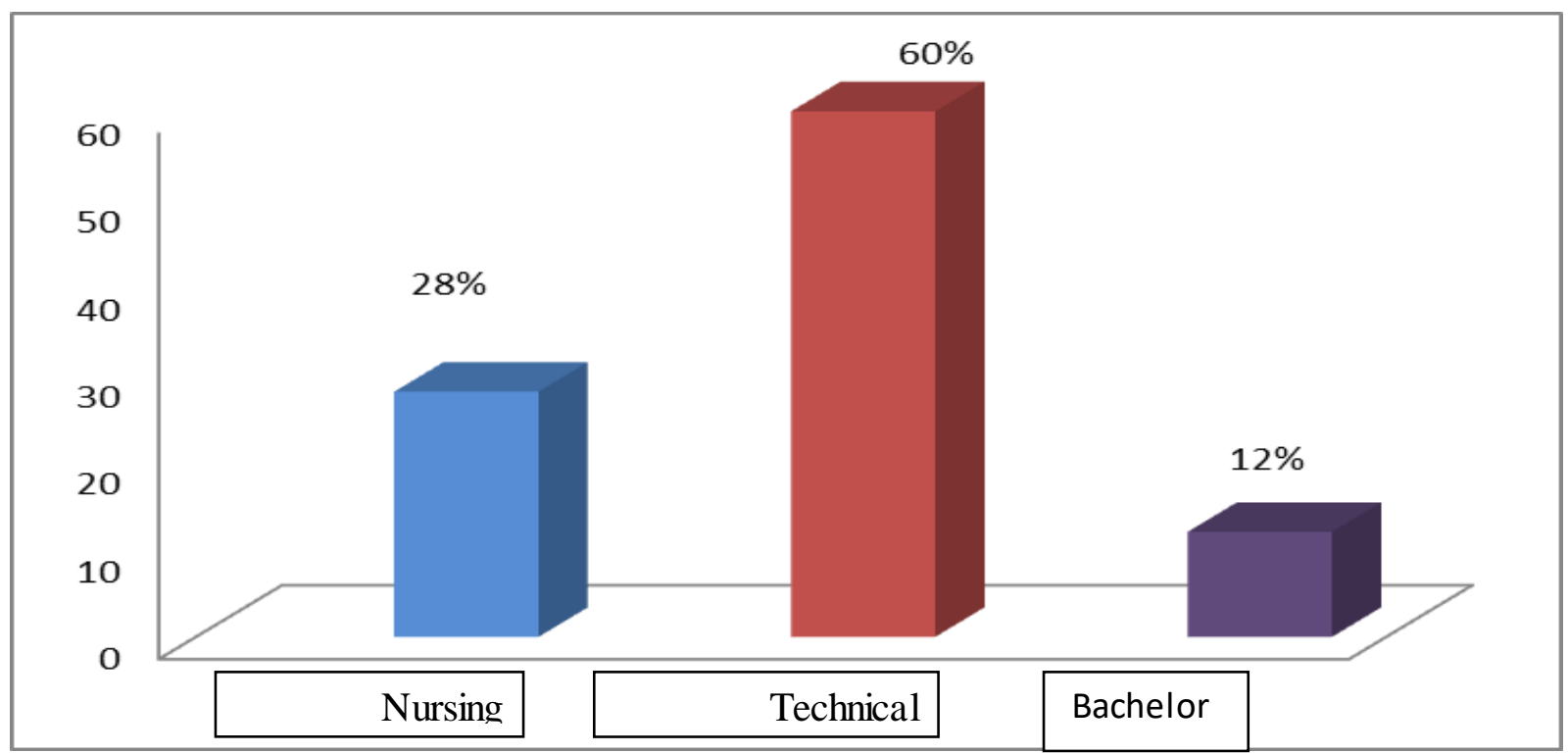

Figure (2): Distribution of the Studied Nurses According to their Educational level $(n=25)$.

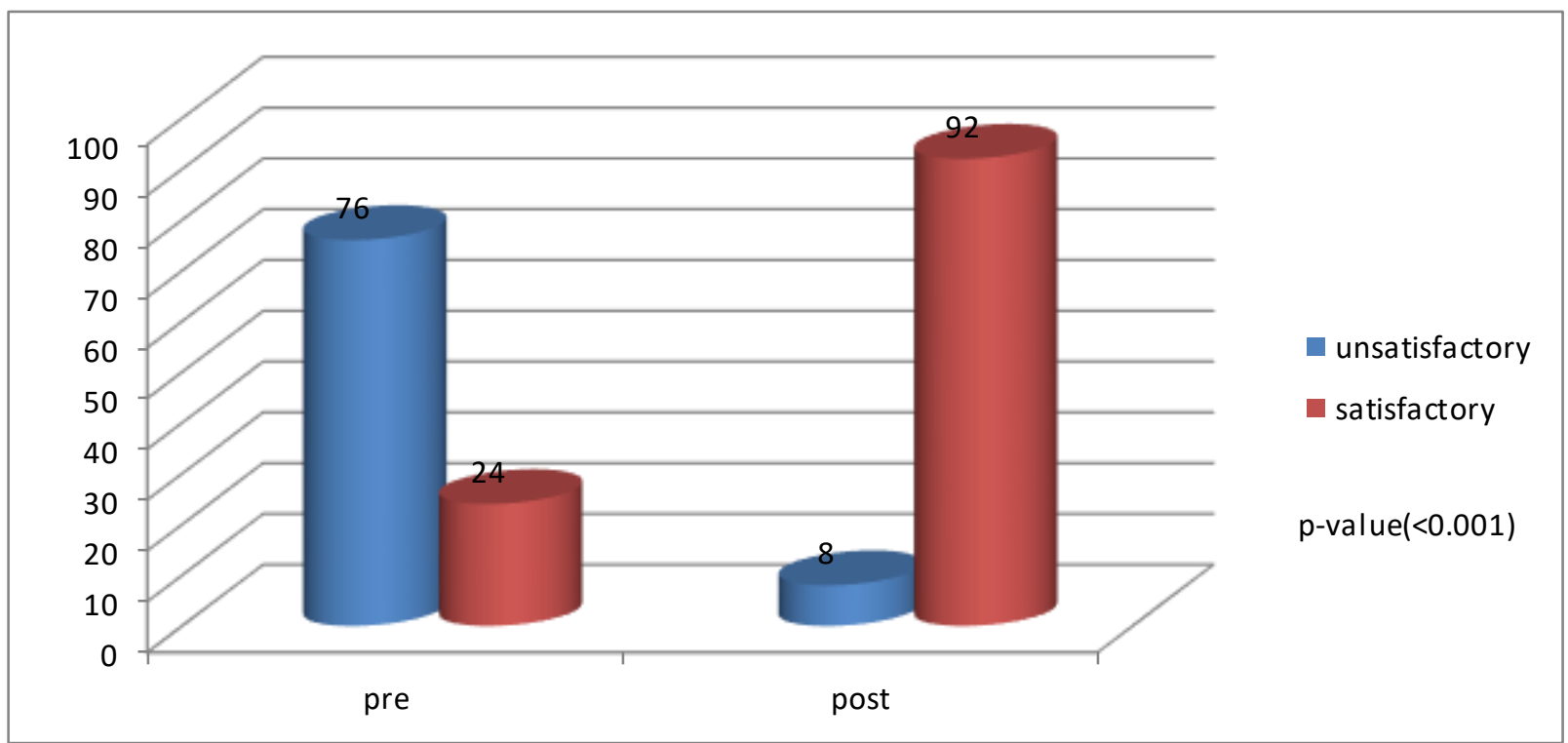

Figure (3): level of Nurses Total Knowledge satisfaction in Pre and Post Implementation of the Training Program $(n=25)$. 
Table (2): correlation between nurses' knowledge and their demographic characteristics $(n=25)$ :

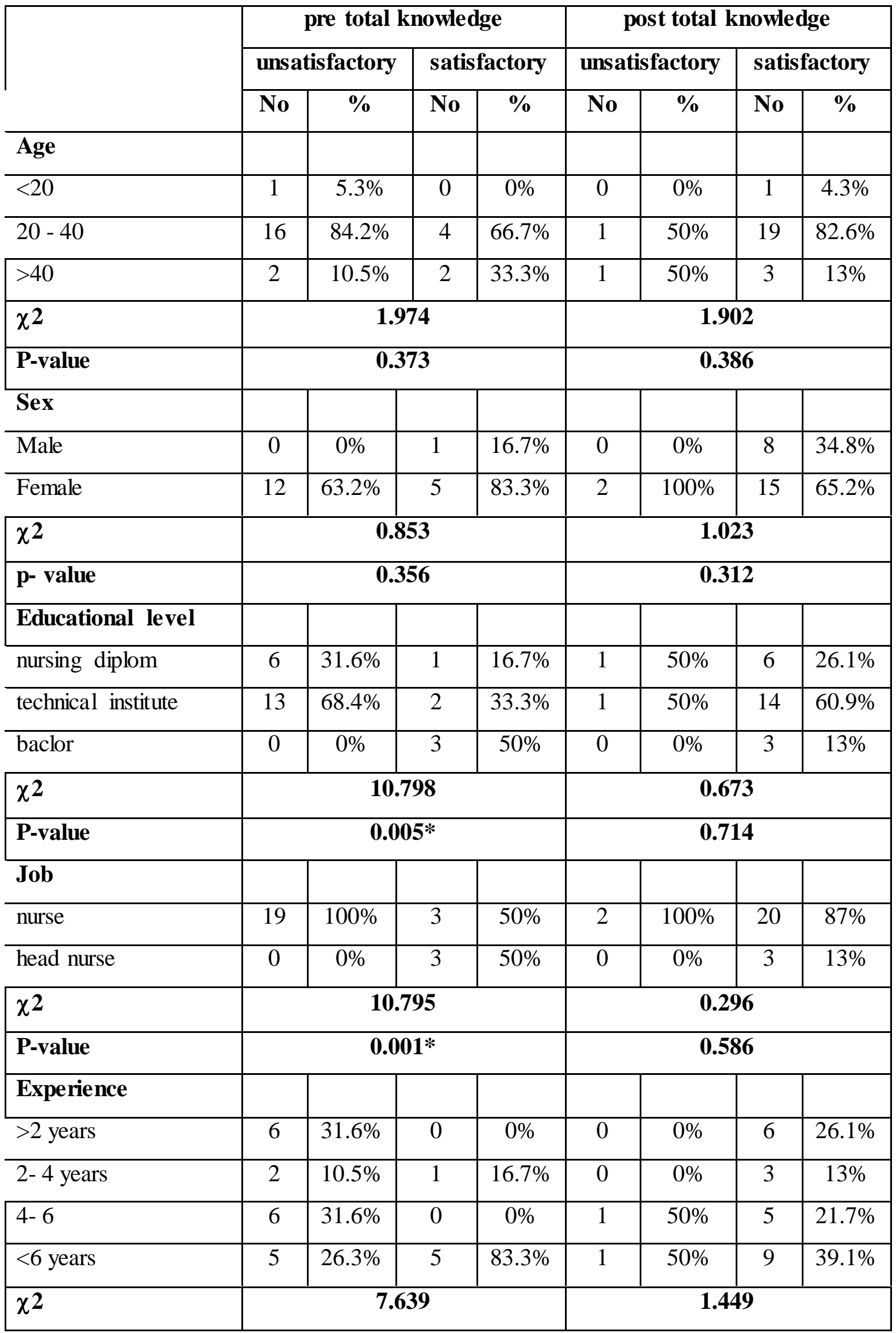




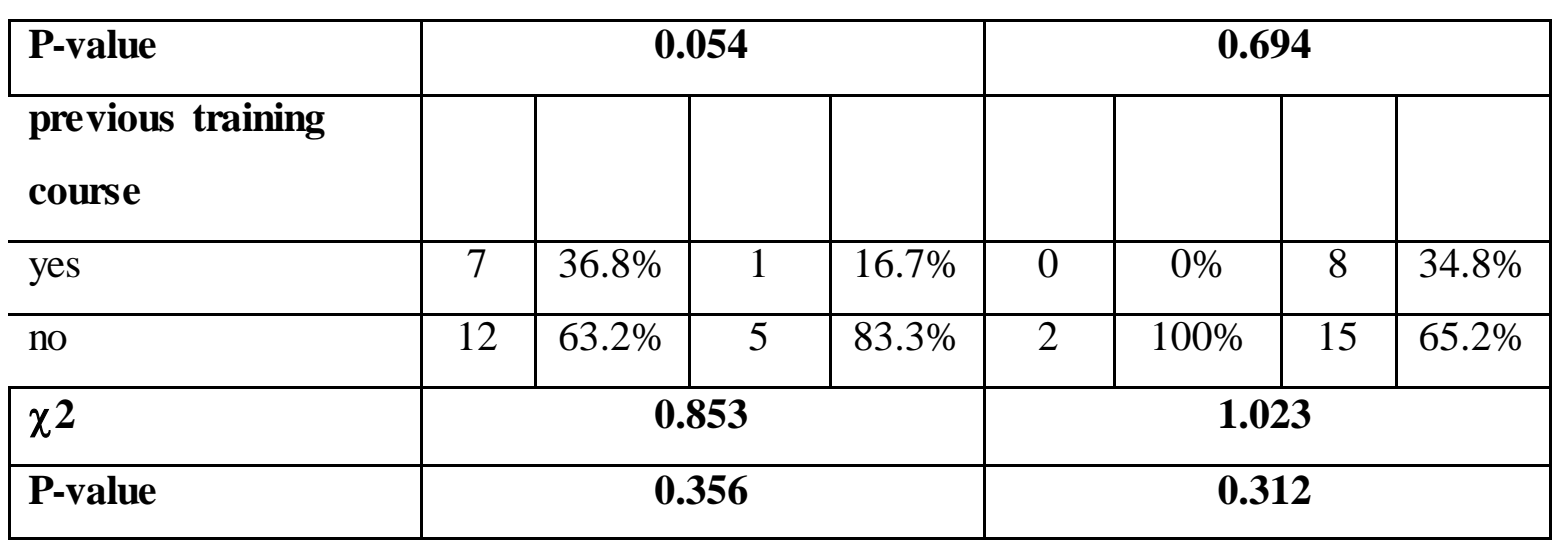

(*) Statistical significant difference, $\mathbf{P} \leq \mathbf{0 . 0 5}$

\section{(x2)chi-square}

\section{DISCUSSION:}

Acute upper gastrointestinal bleeding is common, costly, and potentially lifethreatening medical emergency and requires prompt assessment and aggressive medical management .Elderly patients and those with chronic medical diseases as liver cell failure, chronic renal failure and ischemic heart disease withstand AUGIB less well than younger, fitter patients, and have a higher risk of death (Reda, Montasser, Saleh, Hassan \& Ewis, 2015).

The finding of present study revealed that, more than three quarter of the nurses' age ranged from 20 to 40 years old. More than two third of them are females and two third of them have technical institute level of education. These findings are in accordance with Mohamad, Mohamad \& Sayed, 2014, whom found that, the majority of nurses in GI endoscopy unit their age ranged from 20 to 30 years old, all of them were females and less than two third of them had diploma of nursing.

Concerning years of experience, the present study revealed that less than half of the study nurses have more than 6 years of experience. This finding goes in the same line with Mohammed, 2011, who report that more than half of the study group of nurses dealing with hematemesis patients had experience more than five years. Also this finding is in agreement with Sayed, 2018, who reported that about half of nurses working with hematemesis patients their experiences were mostly more than five years.

Regarding previous training courses, more than two thirds of the studied nurses did not have previous training program regarding nursing care of patients with upper gastrointestinal bleeding. This finding goes in accordance with Sayed, 2018, who found that more than half of nurses working with hematemesis patients did not receive previous training about infection control. Also in the same line Amer, Taha \& Zaton, 2015, 
reported that less than two thirds of the studied nurses of upper gastrointestinal endoscopy did not have previous training program. This might be due to education and training, including competency testing, at least annually.

The results of the current study reveal that, about three quarter of the studied nurses in pre training program implementation had unsatisfactory level of total knowledge about care of patients with upper gastrointestinal bleeding, while in post implementation of the training program, the most of nurses had satisfactory level of total knowledge with a highly statistical significant differences at all phases of implementing the training program .This might be due to the positive effect of training program on nurse's knowledge and practice and might be due to more than two thirds of the nurses of the present study did not have previous training program regarding nursing care of patients with upper gastrointestinal bleeding .

This finding is similar to Mohamad, etal, 2014, who found that less than half of the nurses had unsatisfactory knowledge in pre designed nursing protocol while in post designed nursing protocol the majority of nurses working with patients undergoing upper endoscopy had satisfactory level of knowledge and with highly statistically significant.

Also our findings are in agreement with Suleiman , 2018 who noted that the majority of participant nurses dealing with acute upper gastrointestinal bleeding in Ibn sinaa hospital had satisfied knowledge regarding initial care of patients with upper GIT bleeding. Additionally the current study is in accordance with Mohammed, 2011, who document that most of nurses dealing with hematemesis patients have unsatisfactory knowledge level pre teaching protocol regarding infection control and nursing care for hematemesis patient, and however all of nurses in post teaching protocol are in good knowledge level.

According to the present study finding, there were a statistical significant correlation between nurse's educational level, job and their total knowledge scores in pre implementation of the training program. This is mean that nurses' knowledge improved with high level of education. This finding is in agreement with Othman, 2018, who mentioned that regarding to relation between socio demographic data and total knowledge of nurses, there is a significant difference between educational level and the total level of knowledge statistically. 


\section{CONCLUSION:}

Based on study findings, it can be concluded that: The training program has a remarkable significant improvement on nurses' knowledge regarding care of patients with upper GIT bleeding.

\section{RECOMMENDATIONS:}

Maintaining an educational booklets, pamphlets, and boosters that contain all instructions and information about upper gastrointestinal bleeding in the hematemesis unit and continuous health teaching training for nurses dealing with upper gastrointestinal bleeding patients using media as television programs, online videos and programs.

\section{REFERENCES:}

Amer, W.M., Taha, N.M., \& Zaton, H.K. (2015). Nurses knowledge and practice regarding gastrointestinal endoscopy and suggested nursing guidelines. Afro-Egypt $J$ Infect Endem Dis, 5(2), 115-130.

Bayumi, H. (2016). Clinical outcomes and patient satisfaction assessment among upper gastrointestinal bleeding at qena university hospital at upper egypt. Journal of Nursing and Health Science, 5 (6), 130-139.

Cerulli, M., \& Geibel, J., (2016). Upper gastrointestinal bleeding. Retrieved from "http://as.medscape.com/js.ng/p

Dewit, S.C., \& kumagai, C.K., (2013). Medical-surgical nursing concept and practice: Care of patients with disorders of The upper gastrointestinal system ( $2^{\text {nd }}$ ed.). Saunders, St. Louis: Elsevier.

Lewis, S.L., Heitkemper, M.M., Dirksen, S.R., Camera, L.M., \& Bucher, L. (2016). Medical-surgical nursing assessment and management of clinical problems: Upper gastrointestinal problems (10 ${ }^{\text {th }}$ ed.). St. Louis: Mosby Elsevier.

Mansoura annual statistical records. (2017). Mortality and morbidity rate. 
Mohamad, A., Mohamad, Z., \& Sayed, Z. (2014). "Esophagogastroduodenoscopy": Impact of a designed nursing teaching protocol on nurse's performance and patient's outcome. Journal of American Science, 10(10), 56-65.

Mohammed, G. (2011). Infection control: Effect of a designed teaching protocol on nurses knowledge and practice regarding to hematemesis patients (Master's Thesis), Assiut University.

Othman, S. (2018). Nursing guidelines for hematemesis patients undergoing upper gastrointestinal endoscopy (Master's Thesis). Faculty of Nursing, Mansoura University.

Reda, M., Montasser, I., Saleh, S., Hassan, A. \& Ewis, A. (2015). Prospective assessment of the rockall risk scoring system in egyptian patients with upper gastrointestinal Bleeding. Open Journal of Gastroenterology, 5(6), 66-76.

Sayed, S. (2018). Infection control: Effect of a structured nursing protocol on practice scores of nurses working with hematemsis patients. Journal of Nursing and Health Science, 7(4), 38-45.

Siau, K., Chapman, W., Sharma, N., Tripathi, D., Iqbal, T., \& Bhala N. (2017). Clinical management of acute upper gastrointestinal bleeding: An update for the general physician. Journal of the Royal College of Physicians of Edinburgh, 47(3), 218-230.

Smith, G. (2012). The management of upper gastrointestinal bleeding. Nursing Times, 100 (26), 40-43.

Suleiman, A. (2018). Nurses performance regarding emergency management of patient with acute upper gastrointestinal bleeding in ibin sinaa hospital(Master's Thesis, Neelain Repository). Retrieved from http/hdl.handle.net/123456789/12310.

Tielleman, T., Bujanda, D., \& Cryer, B. (2015). Epidemiology and risk factors for upper gastrointestinal bleeding. Gastrointestinal Endoscopy Clinics of North America, 25 (3), 415-428.

Urden, L. , Stacy, K., \& Lough, M. (2015). Priorities in critical care nursing: Gastrointestinal disorder and therapeutic management ( $7^{\text {th }}$ ed.): Mosby Elsevier. 


\section{تأثير تطبيق برنامج تدريبى تجاه العنايه بمرضي نزيف الجهاز الهضمي العلوي على معلومات الممرضين}

م/نسمه السيد احمد مندور-أ.د. السيد عبد المقصود خليل- أ.م .د إيمان صالح شاهين- أ.م.د شرين أحمد أحمد

$$
\text { قلاوة. }
$$

$$
\begin{aligned}
& \text { ماجستير التمريض الباطني والجر احي -كليه التمريض -جامعه عين شمس. } \\
& \text { أستاذ الباطنه بكلية الطب - جامعة المنصورة. } \\
& \text { أستاذ مساعد بقسم تمريض الباطني و الجراحي ـ كلية التمريض - جامعة بورسعيد. } \\
& \text { أستاذ مساعد بقسم تمريض الباطني و الجراحي ـ كلبة التمريض - جامعة بورسعيد. }
\end{aligned}
$$

\section{الــــلاصـــة}

الدراسة الحالية دراسة شبه تجريبية هدفها تقييم تأثير تطبيق برنامج تدريبى تجاه العنايه بمرضلى نزيف الجهاز

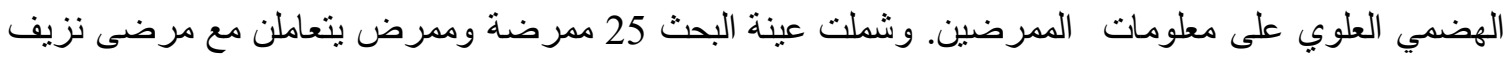

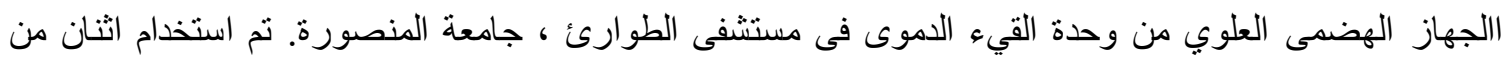
أدوات لجمع البيانات, بيانات شخصيه و استبيان تقييم المعلومات لدى الممرضين وخلصت نتائج الدراسة الحالية إلى في وجود تحسن كبير إحصائًا في المعرفة الكلية للممرضين وذللك بعد تنفيذ البرنامج التدريبى. ونستخلص من الدراسة إلى أن البرنامج التدريبيى لله تأثير إيجابي ملحوظ بمعلومات الممرضين. وأوصت الدراسة بالتخطيط لبرنامج التدريب المستمر وتقديمه بانتظام للممرضين في وحدة القيء الدموى وأيضا التقييم المستمرلهم من قبل مشرفيهم وذللك لتحسين معرفتهم فيما يتعلق برعاية التمريضيه لمرضى نزيف الجهاز الهضمى العلوي.

$$
\text { الكلمات الرئيسية: برنامج تدريبى - نزيف الجهاز الهضمي العلوي }
$$

